$\frac{152}{3 / 13779}$

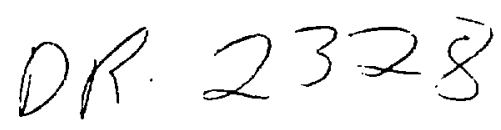

\title{
MASTER
}

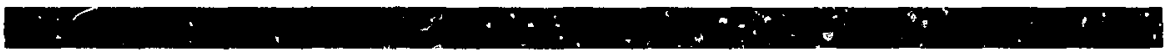

\section{TRITIUM-CONTAINMENT SYSTEMS: A TRADEOFF STUDY}

\author{
C. L. Folkers \\ R. J. Cena
}

Deccmber $18,197 \%$

Work carformad under the auspuces of the US Department of

Energy by the UCLLL under contract number W.7405.ENG-4B

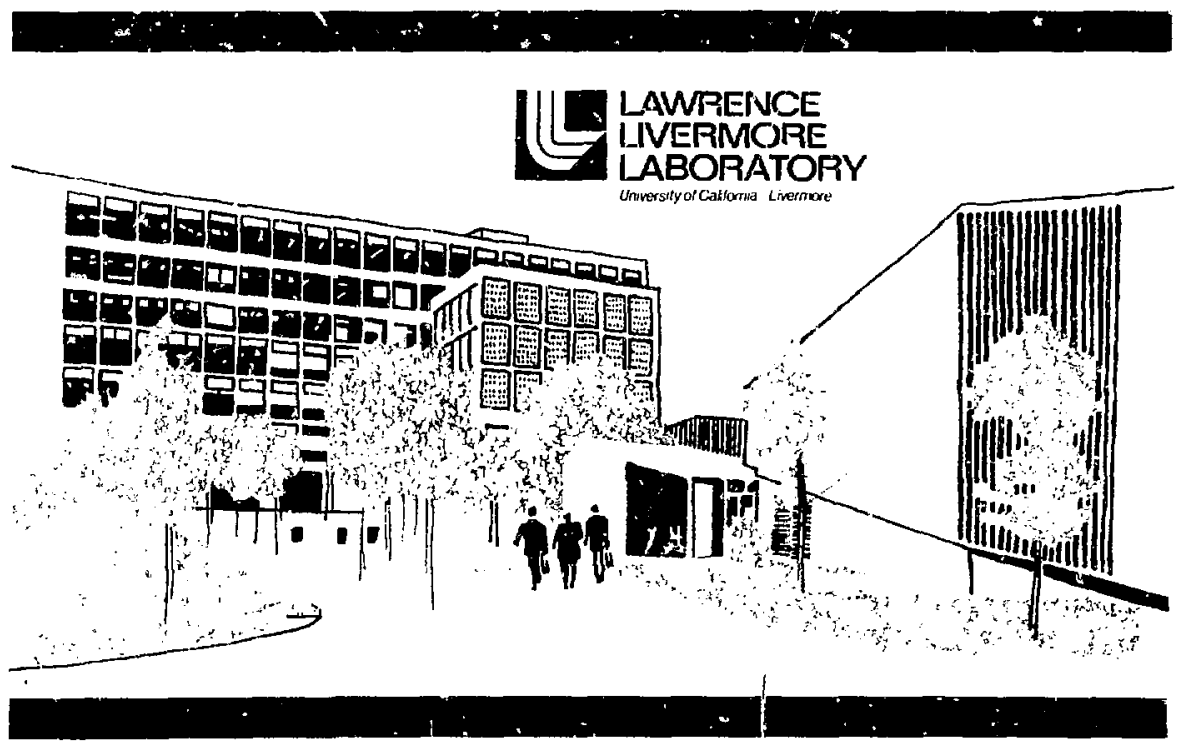




\title{
15 \\ I AWRENCE LIVERMORE I_ABORATORY \\ Unversityot Caltorna Livermore. Callorna 94550
}

UCAL-52627

\section{TRITIUM-CONTAINMENT SYSTEMS: A TRADEOFF STUDY}

\author{
C. L. Folkers \\ R. J. Cena
}

MS. date: December 18, $19 ? 8$

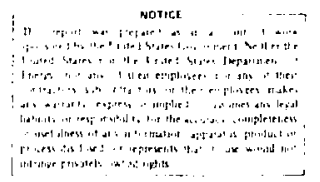




\section{CONTENTS}

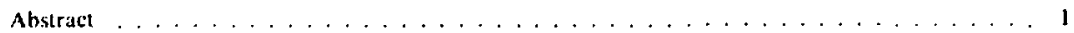

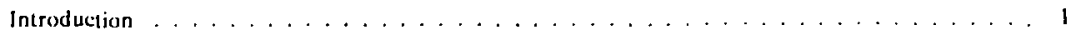

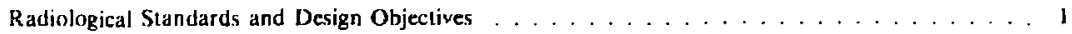

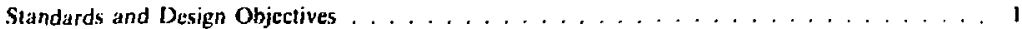

Fenceline ard Uncontrolled-Area Exposures . . . . . . . . . . . . . . . 2

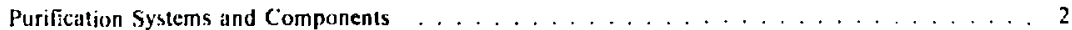

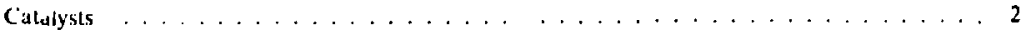

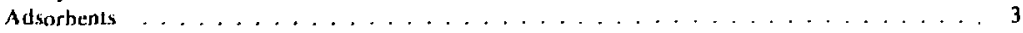

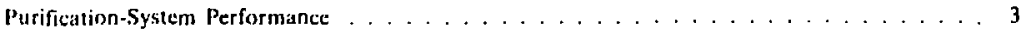

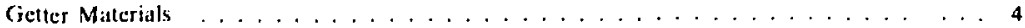

Containment-System Design Requirements . . . . . . . . . . . . . . . . . 4

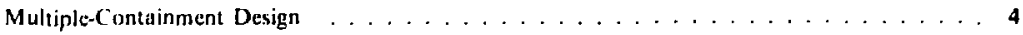

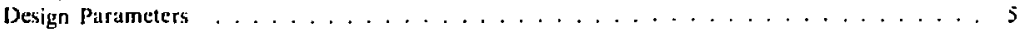

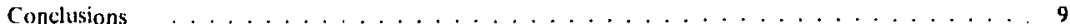

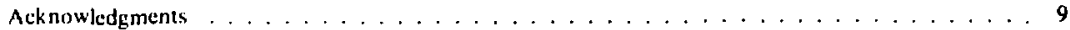

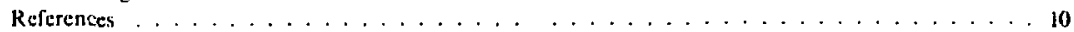




\section{TRITIUM-CONTAINMENT SYSTEMS: \\ A TRADEOFF STUDY}

ABSTRACT

We evaluated various design parameters that affect the performance of tritiumcontainment systems for fusion reactors. Our sludy included a review of such parameters as tritium forms, impurities, catalysts, adsorbents, getters, and "as low as reasonably achievable" principles. We organized these schemes, which can be considered for treating either air or inert atmospheres, so one could easily make orderly choices and tradeoffs for optimum performance. The relationships examined involved purification-system decontamination lactors, flow rates, recycling and leakage. and environmental losses.

\section{INTRODUCTION}

Fusion-reactor facilities, which will handle large inventories of tritium, will have processing equipment that will inevitably suffer leakages and accidental losses. Containment systems must be provided to (a) minimize the tritium exposure of plant persorinel and the general public and (b) recover the tritium for reuse or disposal.

The designer of tritium-containment systems must address an array of performance requirements. These range from government regulations conetrning exposures and release rates to the effects of system leakage on the required design efficiency.
Some containment systents will be large and expensive, and thus poor designs could be costly if not dangerous.

This report especially concerns facturs affecting overall system performance. We have organized these parameters so orderly choices and tradeoffs for optimum performance and cost can be easily made. Reiationships involving purificationsystem decontamination factors, flow rates, recycling and leakage, and environmental losses are presented graphically.

\section{RADIOLOGICAL STANDARDS AND DESIGN OBJECTIVES}

Minimization of radiological exposures is the ultimate goul of containment systems. Radiological design guidelines provite the basis for establishing performance criteria for tritium-containment and -purification systems.

\section{STANDARDS AND DESIGN OBJECTIVES}

Fusion reactors can be expected to mee the radiation-exposure standards imposed on light water-cooled reactors ${ }^{\mathrm{I} 3}$ (Table 1). We are also expeeted to maintain "as low as reasonably achievable" (ALARA) exposures for workers and the general public.
The Nuclear Regulatory Commission (NRC) also requires that the annual integrated population dose (man-rem) within $80 \mathrm{~km}$ ( $50 \mathrm{mi}$ ) of a source be

TABLE 1. Radiationexposure guidelines for light watercooled reactors.

\begin{tabular}{cl}
\hline $\begin{array}{c}\text { Controlled area } \\
\text { (mrem/yr) }\end{array}$ & \multicolumn{1}{c}{$\begin{array}{c}\text { Uncontrolled area } \\
\text { (mrem/yr) }\end{array}$} \\
\hline 5000 (limit) $^{1}$ & \multicolumn{1}{c}{-} \\
- & 25 (limit) $^{2}$ \\
- & 5 (decign objective) $^{3}$ \\
\hline
\end{tabular}


used to determine the environmental impact. NRC speciffes a value of $\$ 1000 /$ man-rem exposure to assess the cost/benefit of equipment io further reduce emissions. "

\section{FENCELINE AND UNCONTROLLED-AREA EXPOSURFS}

The atmospheric dispersion of radianuclides following a release can be calculated by the procchlures for noble-gats releases for light-water reactors. 4 We have arbitrarily chosen to use the "river site" locittion along with the normalized dispersion coeflicieith and population histograms given in Ref. 4.

Using the uncontrolled-area design objective of $5 \mathrm{mrem} / \mathrm{yr}$ for individuals at the site boundary, we calculated maximum releasc rates for $10-$ and $100-\mathrm{m}$ stacks and the corresponding lotal population exposures (Table 2). Incruasing stack height permits much larger maximuin tritium.release rates, even though large reactor halis are tinlikely to have stacks as low ts this $10 \mathrm{~m}$ illusiration.

Emissions of $\sim 890$ ( $i / d$ from a $100-m$ stack will meet both the design objectives and the
ALARA philosophy. Existing tritium facilities operate with emissions aboul a factor of 100 lower. ${ }^{5.6}$ Istimates for fusion reactors are also a factor of I 00 jower than calculated above. ${ }^{7.9}$

If we select an emission rate of $10 \mathrm{Ci}_{\text {d from a }}$ $10(1) \mathrm{m}$ stack, the fenceline exposuse will be 0.00 $\mathrm{mrem} / \mathrm{yr}$, and the total population exposure will be $12 \mathrm{man}-\mathrm{rem} / \mathrm{yr}$. These lower values will fulfil] the AI.ARA philosophy and can be achieved by present technology.

We alse note that natural tritium production in the northern hemisphere is about $10 \mathrm{Ci} / \mathrm{d}$. 10 Hundreds of "Il/ Ci/d" plants coun - operated before douhling the rate of atmospheric production.

TABLE 2. Maximum (ritism-release rates for uncontrolled areas and total population exposures within $80-\mathrm{km}(50-\mathrm{mi})$ radius for "river site."

\begin{tabular}{rccc}
$\begin{array}{c}\text { Stack } \\
\text { liciglit } \\
\text { (ni) }\end{array}$ & $\begin{array}{c}\text { Maximum } \\
\text { retejse rate } \\
\text { (Ci/L) }\end{array}$ & $\begin{array}{c}\text { Total } \\
\text { population- } \\
\text { exposure } \\
\text { ratc/relcasc rate } \\
\text { (man-rem/yr)/(Ci/d) }\end{array}$ & $\begin{array}{c}\text { Total } \\
\text { population } \\
\text { exposture } \\
(\text { mon-rem/yr) }\end{array}$ \\
\hline 10 & 6.4 & 6.0 & 38 \\
100 & 890 & 1.2 & 1070 \\
\hline
\end{tabular}

\section{PURIFICATION SYSTEMS AND COMPONENTS}

Purification systems can be designed to scavenge tritium cither from air or from inert gatses. Several systems are operating successfully with air atmospheres, $5,11.14$ and most, reactor halls are expected to use air. Glove buxes often use inert atmospheres, 5,12,15 and at least one recent reactor design contemplates inert gas in a reator hall. Is

Catalytic oxidation-adsorption systems are used with air-tritium mixtures. These systems include the following features:

- Tritium may be scavenged as gas (HT), water (HTO), or organic vapors (termed $\mathrm{CH}_{3} \mathrm{~T}$ ).

- Any gas with sufficient oxygen can be processed.

- Tritium is, recovered at HTO.

- Contaminated air atmospheres will still be life-supporting for workers in an emergency.

Active metal (hydride) getter systems can be used with inert gas-tritium systems. These systems include the following features;
- Tritium is scavenged anć recovered at HT, but $\mathrm{HTO}$ and $\mathrm{CH}_{3} \mathrm{~T}$ must be low.

- Inert atmospheres must be used.

- Systems can use packed or Muidized beds.

- Metal getters may be firc hazards if exposed to air.

\section{CATALYSTS}

Proven catalysts for oxidation of tritium include the precious metals platinum (Pt) and palladium (Pd) and mixtures of about $101020 \mathrm{wt} \%$ of copper oxide in manganese dioxide called Hopcalite* Both will oxidize $\mathrm{HT}$ and $\mathrm{CH}_{3} \mathrm{~T}$, are more effective when heated, and are affected by poisons.

The most extensive kinetic data for oxidation of $\mathrm{HT}$ and $\mathrm{CH}_{3} \mathrm{~T}$ by precious metal catalysts is by

Trademark of Minc Safety Appliances Company. 
Bixcl and Kershner. ${ }^{17}$ Sheswood modified their reaction rate equation for pore diffusion: his estimates for cutalys efficiericy as a function of temperature, residence time with the catalyst, and superficial selocity are show $n$ for HT in Fig. I. to

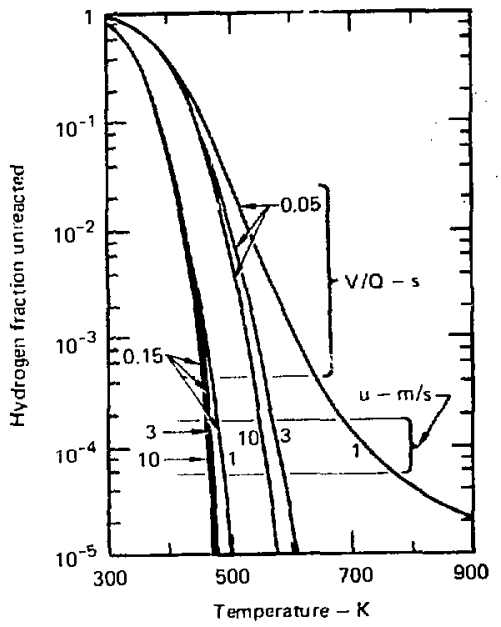

FIC. 1. Catalyst efficiency for two volues of residence time, $V / Q$, and three values ot superficial velocity, u. (alculated for $\mathrm{Pt} / \mathrm{Al}_{2} \mathrm{O}_{3}$ catalyst bed with particle diam, $d_{p}=3.18 \mathrm{~mm}$ and void fraction, $E$ $=0.4$ (Sherwood ${ }^{(\mathrm{k}}$ ).

Poisons affecting precious metal cutalysts include mercury, hulogens, silicones, carbon monoxide (CO). and sulfur compeunds. 19-21 Hopcilite is affected by some halogens and CO. 19.22.23 In onc installation, an activated charcoal filter scavenges poisons ahead of the catalyst. ${ }^{12}$

Hydrocarbons all require hot catalysts for oxidatuon, ranging from 150 to $415^{\circ} \mathrm{C}$. 19,20 The lightest compounds [e.g., methane $\left(\mathrm{CH}_{4}\right)$ and ethane $\left.\left(\mathrm{C}_{2} \mathrm{H}_{6}\right)\right]$ require the highest temperatures. 19.24.25 Manufacturers's datil for Hopcalite appear in Fig. 2.

Catalyst efficiencies apparently decrease at ") leemely low HT levels. ${ }^{15,26}$ Some systems add hydrogen $\left(\mathrm{H}_{2}\right)$ in an attempt to "stamp." or reduce. unuxidized $\mathrm{HT}$ leaving a catalyst bed. 13.27

Circulation pumps may add energy to the gasses as heat of compression. This is used as pleheal energy for better catalyst performance in several systems. 11.1.1.27

Gallow ay noted the high cost of precious melal

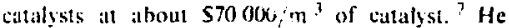
inferred a conctrn for costs by sh. wwing that cleanup time will vary inversely with the eatulys volume (Fig. 3) ${ }^{2}$ The cost of Hopealite is about $\$ 7200 / \mathrm{m}$ ? of catialyst.

\section{ADSORBENTS}

Common adsortent materials include molecular sioves, artivated alus. ina. and silica gel. The first two are capable of drying gasses to less than 0.1 Pit (-1 ppm) HTO: silica get can dry gilssests to aboul I Pa (-10 ppmi) HTO. Adsorbenı beds for tritium service are deseribed by Sherwoud 18 ard Gallowis. "

Adsorbent beds siturated with water $\left(\mathrm{H}_{2} \mathrm{O}\right)$ can be used as isotopic exchange columns to scuvenge HTO. 9.11 .13 .29 Tritiun scavenged this way, lowever, will be diluted with large amounts of $\mathrm{H}_{2} \mathrm{O}$ and will be difficult to recover for reuse.

Adsorbent beds can also be operated at tryogenic temperatures for direcl adsurption of virtually al! impuritics, without requiring catalytic oxidation. 5.11

\section{PURIFICATION-SYSTEM PERFORMANCE}

The most detailed perfurmance results for a catalvtic oxidation-adsorption system are reported by Gildea e! al., ${ }^{14.30}$ and are reproduced in Fig. 4 for $\mathrm{H}_{2}$ and $\mathrm{CH}_{4}$. Sherwood reported one point for a comparable system with HT, ${ }^{31}$ also shown in Fig. 4. The data show that the presence of any tritiuted organics will require hot catalysts.

Two points are also shown in Fig. 4 for a calalytic oxidution-exchange colunn system using HT, by Flanagan. Rogers, and Wilkes. "I We believe the general agreement with the data for adsorption systems is remarkably good.

The isotopic swamping technique noted earlier can also be used with adsorbent beds. One bed is 


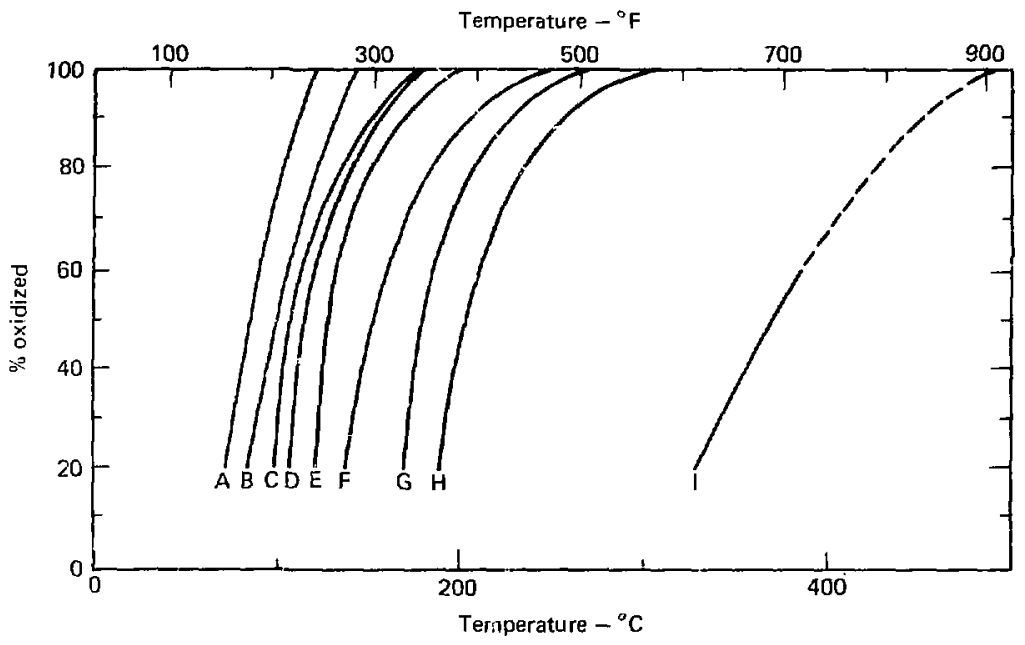

FiG. 2. Combustion of various contanninents over Hopcalite catalyst (Mine Safety Appliances part 26599) as a function of tempersture (MelDonough ${ }^{25}$ ). $\mathrm{A}$ = butsene, $\mathrm{C}_{4} \mathrm{H}_{8} ; \mathrm{B}=$ hexane, $\mathrm{C}_{6} \mathrm{H}_{14} ; \mathrm{C}=$ acetylene, $\mathrm{C}_{2} \mathrm{H}_{2}$ and carbon monoxide, $\mathrm{CO} ; \mathrm{D}=$ propylene, $\mathrm{C}_{3} \mathrm{H}_{6} ; \mathrm{E}=$ ethylene, $\mathrm{C}_{2} \mathrm{H}_{4} ; \mathrm{F}=$ butane, $\mathrm{C}_{4} \mathrm{H}_{10} ; \mathrm{G}=$ propane, $\mathrm{C}_{3} \mathrm{H}_{8}$ and hydrogen, $\mathrm{H}_{2} ; \mathrm{H}=$ ethane, $\mathrm{C}_{2} \mathrm{H}_{6}$ and benzene, $\mathrm{C}_{6} \mathrm{H}_{6} ; \mathrm{I}=$ methane, $\mathrm{CH}_{4}$.

used to adsorb HTO; then $\mathrm{H}_{2} \mathrm{O}$ is added to the gas stream and a second bed brings down total n.oisture, resulting in lower HTO levels. $13,14,27,30,32$

\section{GETRER MATERIALS}

Active metul getters scavenge HT by forming stable metal hydrides. Candidates include uranium, titanium, zirconium, scindium, yttrium. thorium. and the rare carth series, Uranium and cerium were studied for use as packed beds. ${ }^{33,24}$ Masenschein compared designs for packed and fluidized beds. 25

An unsaturased orgunic material called DPPF* is uiso elfective us a hydrogen getter and is reported stable in air. ${ }^{36,37}$ The organic material is supported on calciurn carionate coated with a Pd catalyst.

\section{CONTAINMENT-SYSTEM DESIGN REQUIREMENTS}

\section{MULTIPLE-CONTAINMENT DESIGN}

The concept of multiple-contairment barriers is generally accepted for tritium control in fusion reactors. 8,3:,38-42 These are defined as primary, secondary, and tertiary conjinement for high-luvel contamination, in the manner specified for certain other facilities. ${ }^{43}$

"1,6-diphenoxy-2, 4-hexudiyne. 


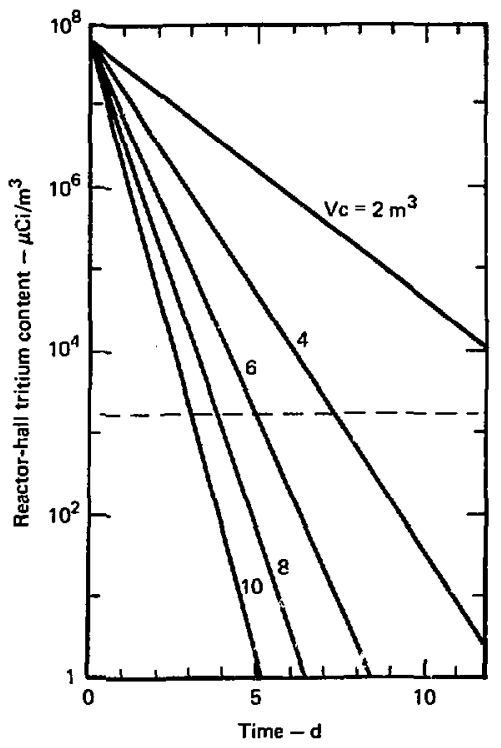

F1G. 3. Tritium reduction on "incredible accident," showing effects of catalyst volume, Vc, on cleanup time. Initial concentration of HTO (tritium scavenged as water) $=65 \mathrm{Ci} / \mathrm{m}^{3}$; reactor-hall volume, $\mathrm{v}=$ $350000 \mathrm{~m}^{3}$ : Now rate, $Q=58.8 \mathrm{~m}^{3} / \mathrm{s}\left(10^{5}\right.$ (fm); temperature, $\mathrm{T}=27^{\circ} \mathrm{C}\left(\right.$ Galloway $\left.{ }^{28}\right)$.

Primary containment refers to the components and equipment in direct contact with tritium. Secondary containment refers to local containment enclosures surrounding pieces or sections of primary equipment. Tertiary containment includes the reactor hall and equipment rooms enclosing all tritium systems, including all containment purification systems.

The multiple-containment concept for a fusionreactor plant can be illustrated by the diagram in Fig. 5, taken from Wittenberg, Wilkes, and Kershner. ${ }^{8}$ Their study details containment concepts as well as explores tritium-source and -leakage terms.

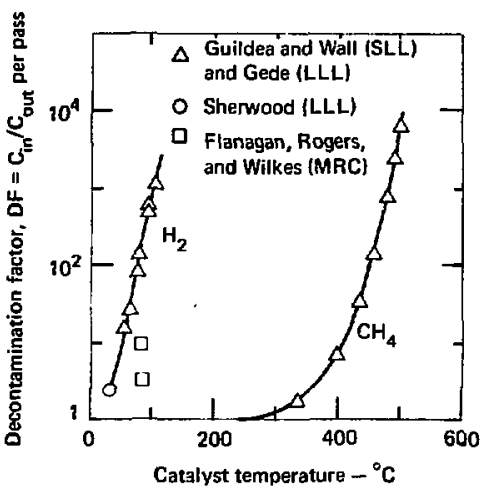

FIG. 4. Purification-system decontemination factors fer $\mathrm{H}_{2}$ and $\mathrm{CH}_{4}$

\section{DESIGN PARAMETERS}

Basic design features for catalytic oxi tionadsorption follow conventional chemical engineering design principles for oxidation by catalytic reactors and adsorption by packed beds. ${ }^{44-48}$ We have already noted applications to tritium service by Sherwood ${ }^{18}$ and by Galloway. ${ }^{9}$ Aune, Cantelow, and Boltin ${ }^{29}$ include design information for exchange columns. We will concern ourselves here more with special effects of system performance, recycling, leakage, and losses to the environment.

Most designs for reactor halls anticipate exponential dilution to low tritium levels. Sherwood derived a model showing the effects of tritium "soaking" into exposed surfaces and subsequent undesirable outgassing effects on this presumed exponential dilution. ${ }^{49}$

The relationships among the design parameters permit us to apply these functions as criteria for design. These include

- Reactor-hall volume, $V\left(\mathrm{~m}^{3}\right)$.

- Purification-system flow rate, $Q\left(\mathrm{~m}^{3} / \mathrm{s}\right)$.

- Purification-system decontamination lactor, $\mathrm{DF}=\mathrm{C}_{\text {in }} / \mathrm{C}_{\text {out }}$ per pass. 


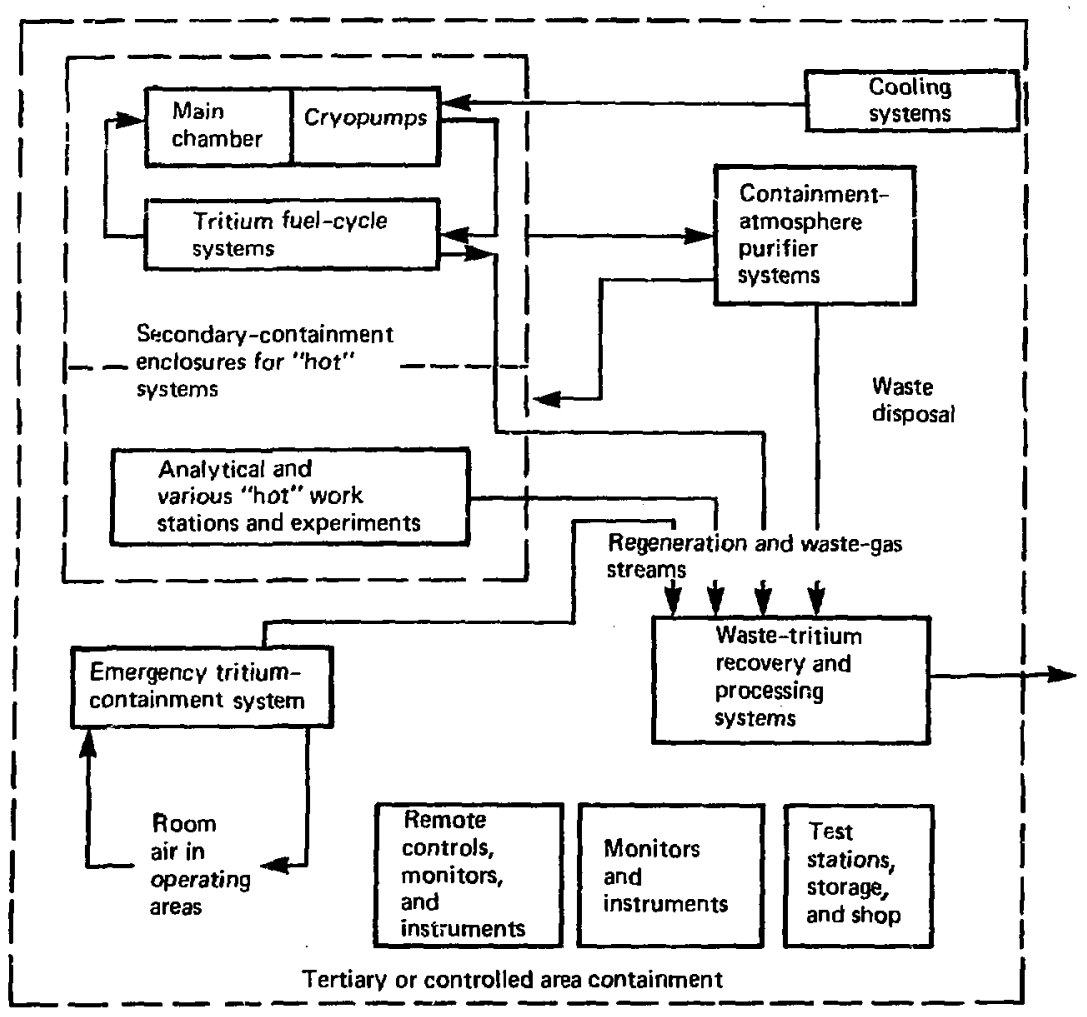

FIG. 5. Multiple-containnent concept for tritium systems in a fusion reactor (Wittenberg, Wikes, and Kershner ${ }^{8}$. 


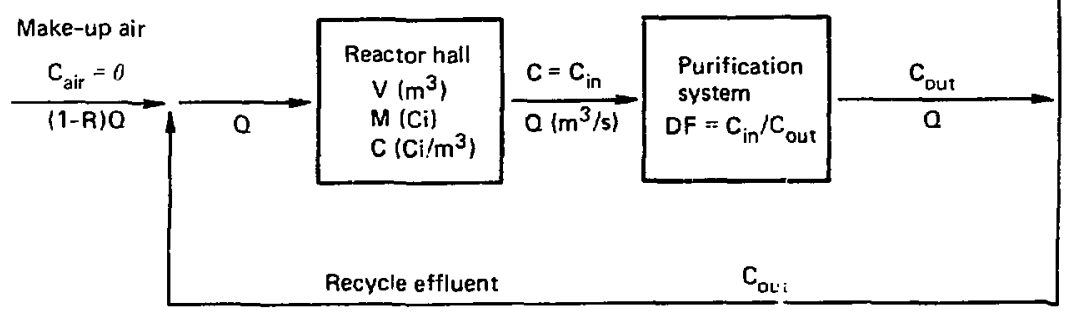

RQ

FIC. 6. Purification-system flow pattern. Initial release $=M_{0}(C i)$ initial concentration, $C_{0}=M_{0} / V_{1}\left(C / m^{3}\right)$.

- Fraction of the purification-system exhaust. R. that is recycled to the reactor hall (from 0 (1) 1.0).

- Time for recovery to a specified level. $t$ (s).

- Reactor-hall cencentration reduction fuctor, $\mathrm{C} / \mathrm{C}_{0}$. expressing the extent of cleanup for a reaclor hill with uny postulited release.

- Origyinal tritium release, $M_{0}(C i)$; tritium remaining in the reactor hall, $\mathrm{M}(\mathrm{Ci})$; and integrated tritiun release to the environment, $M_{L}(\mathrm{Ci})$. Figure 6 shows the general flow patterns iri any containnient system (indicated as a reactor hall). For any initial release, $M_{r-}$ we can show the concentration-reduction factor to be

$$
\frac{C}{C_{l}}=e^{\left(\frac{R}{D F}-1\right) \frac{Q t}{V}},
$$

where $C_{0}=M_{0} / \mathrm{V}$. This can be plotted as a function of the dimensionless time, $Q t / V$, and is shown in Fig. 7 for several values of $D F$ with $R=1.0$. Note tha! the curve for DF $=\infty$ would also apply when $\mathrm{R}=0$.

The designer las several options:

- Values of $V$ and DF can be traded to meet specified values of $\mathrm{C} / \mathrm{C}_{\mathrm{O}}$ and $\mathrm{t}$.

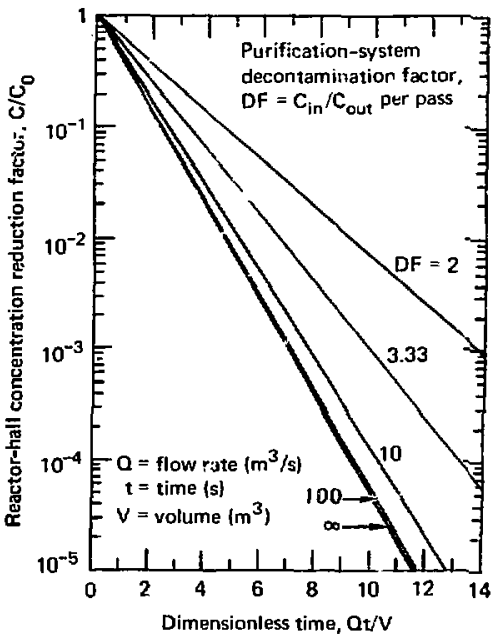

FIG. 7. Reactor-hall concentration reduction factor for several decostamination factors. Fraction recycled, $R=., 0 ; C / C_{0}=\exp \{[(R / D F)-1]$ Qt/V?. 
- A unit cost for a purification system with unit flow rate and a specified DF can be determined. The cost of the number of purifier units to meet specified values of $C / C_{0}$ and $t$ can then be compared to the downtime cost of reaching the specified $\mathrm{C} / \mathrm{C}_{0}$. Increasing capital costs will provide lower (downtime) operating costs.

- Any two of the above parameters can be traded against each other, provided the other lwo parameters are specified.

The amount of ritium released to the environment, $M_{1}$. in the vented exhaust fraction, $I-R$, is derived from the relations

$$
\frac{d M_{L}}{d}=(1-R) Q C_{\text {out }}
$$

for the rate of loss and

$$
M=M_{0} e^{\left(\frac{R}{D T}-1\right) \frac{Q 1}{v}}
$$

for the amount of tritium remaining in the reactor hall. Rearranging and integrating the rate of loss gives

$M_{L}=\left[-\left(\frac{1-R}{D F-R}\right) M_{0} e^{\left(\frac{R}{D P}-1\right) \frac{Q}{V}}\right]_{0}^{t}$ curies .

For latrov values of 1 this can be approximated by

$$
M_{L} \cong\left(\frac{I-R}{D F-R}\right) M_{0} \text { curies }
$$

Thiese results can be plotted as a fraction of the original release, $M_{L} / M_{0}$, vs the decontamination factor, shown for several values of reeycle factor in Fig. 8.

Leakage of untreated gasses from a reactor hall or other lertiary containment can be controlled by operating at a slight negative pressure. The only releases are then in the fraction $(I-R) Q$ as described above.
For any postulaied release or accident, the designer can use the curves in Fig. 8 to trade system tightness. expressed as the fraction recycled, against system performance, expressed as the decontamination factor, to limit releases to the environment as required. Decontamination factors as low as 2 can be effective, given enough time and a tight system.

As an alternate method to minimize environmental releases, $M_{1}$. the efflucnt fraction ( $1-R$ ) to be released can be treated by a smaller purifier having a high DF. The eflluent fraction, $R$, to be recycled can be treated by less efficient purifiers, which are presumably less expensive to build or operate or both.

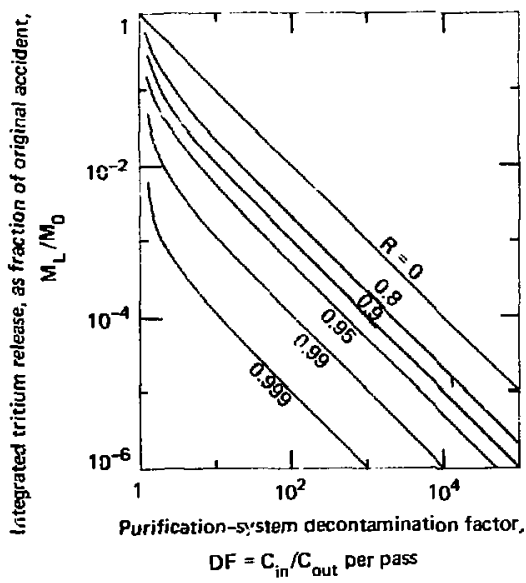

FIG. 8. Integrated tritium release to the environment for several recycle fractions. $R$ - iraction of purification-system exhaust recycked to the reactor hall (it to 1.0). 


\section{CONCLUSIONS}

The radiological standards that will be applied to iritium releases from fusion reactors are more likely to be limited by ALARA principles than by off-site exposure design objectives. Existing technology can limit releases to less than $10 \mathrm{Ci} / \mathrm{d}$, an emission rate that will generally result in off-site exposures well within the design objective.

We reviewed multiple-containment objectives and purification-systen. components. Most tertiary containment systems are ex iected to have air atnospheres, requiring catalytic oxidationadsorption systems. Tritium as HT can be effectively scavenged at or near room temperature. However, the likely presence of organically-bound tritium $\left(\mathrm{CH}_{3} \mathrm{~T}\right)$ or catalyst poisons (e.g.. $\mathrm{CO}$ ) or both will isquire temperatures from -350 to $500^{\circ} \mathrm{C}$ for precious metal and Hop'alite catalysts or else provision for replaccable filters to trap these materials.

Major parameters affecting system design arc presented graphically. These figsres will assist a designer in meking orderly choices for optimum system performance and cost. We note that purification systems having only modest decontamination fictors may be quite satisfactory. if all gasses are recycled and adequate cleanup time is allowed. However high decontamination factors are needed $u$ t.enever the purified effuent is to be released to the enviro iment.

\section{ACKNOWLEDGMENTS}

We wish to express our appreciation to A. E. Sherwood for many helpful comments and suggestiorıs, to R. M. i. Alire and S. A. Steward for reviewing this manuscript, and to $T$. $R$. Galloway for his encouragement. We also wish to thank T. $M$.
Flanagan, M. L. Rogers, and W. R. Wilkes for the results of their experiments, which were funded as a part of this study, and P. D. Gildea. W. R. Wall. and V.P. Gede for performince data from their experiments, which were funded from other sources. 


\section{REFERENCES}

1. Code of federal Regulatiom, 7ïle 10. Chopter / (Nuclear Regulatory Commission, January 1977). Part 20, pp. 144-172.

2. C'sde of Federal Regularions. Title 40). Chapeer / (Environmental Protection Agency, Wash., D.C.. July 1977). Subchapler I. Radiation Protetion Programs, Part 190, np. 413-415.

3. Code of Fiderol Regulations. Tinle 10, Chopler / (Nuclear Regulatosy Commission, January 1977). Part 50. pp. 250).327

4. Final finvirommental Sitalemem Concerning Proposed Ruk Making Acsion: . Dumerical Guides for Design Ohyectives and limising Conditions for Operation to Meet the Criterion 'As Iow as Procticable' for

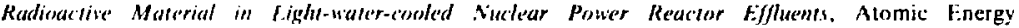
Commission, Wash., I). ., FEIS-AA-73-1252-1:-I, WASH 1258, Vol. 1-3 (I973).

5. C. J. Kershner and J. C. Bixel, "Tritium Eflluent Control Laboratory." in Proc. /3th AEC Air Cleaning Cimf., (ONF-740Ro7 1975 (Atomic Energy Commission, Wash, D.C.. 1975).

6. W. J. Silver, (. I. L.indeken, K. M. Wong, E. H. Willes, and J. H. White, Enirommental Monitoring at the Lawrence Livermore Laboratorl, 1977 , Ammal Report, Lawrence Livermore Laboratory, Livermore. (alif., UCRL-50027-77 (1978).

7. T. R. Galloway, Fritium Management in Fusion Reactors, L_uwrence Livermore Laboratory, Liverm sre, Calif, UC" L-80479) (1978).

8. J.. J. Willenherg. W. R. Wilkes, and C. J. Kershser, "Environmental Control of the Tritium Inventory in a Fusion Ruactor Facility." in Pros. 2nd Topical Mfg 7 ecre of Comerolled Naclear Fusion. CONF-76093.5. 1976 (Superintendent of Documents, Wash., D.C.. 1976).

9. T. R. Gialoway. "Tritium Handling in the Mirror Fusion Hybrid Reactor," in Proc. 7rh Simp. Fing. Problems Fission Res., IELE Puh. No. 77CH/267.4.NPS, 1977 (Institute of Electrical and tilectronics Fingineers, New York (ity, 1977).

10. D. G. Jacobs, Sunrces of Tritum and lis Buhavior upon Release to the Envirmment, Atomic Energy Commission, Wash., D.C. (1968).

11. T. M. Flanagan, M. L. Rogers, and W. R. Wilkes, Experiments wirh a Tritium Emergency Comianment System, Mound Facility, Miamisburg, Ohio. MLM 2528 OP (1977).

12. J. L. Anderson. F. A. Damiano, and J. E. Nasise, "Tritium Handling Facilitics at the Los Alamos Scientific Iaboratory," in Proc. 23rd Conf. Remote Systems Tech. CRSTBJ 23, 1975 (Americ an Nuclear Society, Hinsdale, 111., 1975).

13. T. B. Rhinehammer and P. H. Lamberger, Tritium Contol Technology, Mound Laboratory, Miamisourg, Ohio, WASH 1269 (1973), pp. 218-229.

14. P. D. Gildea, W. R, Wall, and V. P. Gede, Results of Tritium Tests Performed on Sandia Lahoratories Decontamination System, Sandia Laboratories, Livermore, Calif., SAND77-8766 (1978).

15. T. B. Rhinehammer and P. H. Lamberger, Tritium Control Tecinnology, WASH 1269 (1973), pp. 240-244.

16. J. T. D. Mitchell, "Blanket Replacement in Toroidal Fusion Reactors," in Proc. 3rd Topical Mtg. Tech. of Controlled Nucl. Fusion, 1978, to be published by the American Nuclear Sociely, Hinsdale, III.

17. J. C. Bixel and C. J. Kershner, A Study of Catalytic Oxidation and Oxide Adsorption for tho Remotal of Tritium from Air. Atomic Energy Commission, Wash., D.C., WASH-1332 (1974).

18, A. E. Sherwoud, "Tritium Removal from Air Streams by Catalytic Oxidation and Water Adsorption," in Proc. 24ih Conf. Remote Systems Tech. CRSTBJ 24, 1976 (American Nuclear Society, Hinsd:le, Ill., 1976).

19. J. K. Musick, F. S. Thomas, and J. E. Johnson, "Catalytic Oxidation Studies in the Vapor Phase Using Axial Sampling of the Bed," Ind. Fing. Chem., Process Des. Develop. 11, 350 (1972).

20. R. H. Johns, "Kinetics and Catai : 1 Felection in the Combustion of Atmospheric Trace Contaminants," Chem. Eng. Prog. Symposium Series 62 (63), 81 (1966).

21. R. W. Kent, $A$ Guide to Catalytic Oxidation, Oxy-Catalyst, Inc., West Chester, Pennsylvania, promotional literature. 
J. K. Muslck and I. W Williams. "Catalytic Decomposition of Halogenated Hydrocarbons over H. npealite Catalys," Ind. Ens (he'm. Prud. Res. Develep. 13. 175 (1974).

23. J. Ch. Chrian and J. l. Johnson. "Catalytic Combustion of Atmospheric Contaminants over Hiopealite." Im J fir Itat. Poll. 9. I (1965).

24. j. K. Muaich and 1. W. Williams. "Hopealite Catalyst for Catalytic Oxidation of Gases and Aerosols," Ind fing (hum., Prod Res, Des, 14, 284 (1975).

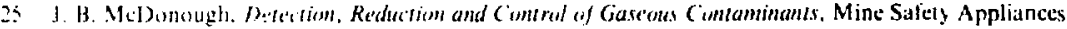
(ampans. Flter Produts Division, Eans Cits. Pennsylvania. promotional literature.

26. I. F. Belesedsk ii, V.K. Gaevoi, V. I. Grishnanovikii. V. V. Andramanow V. V. Demenyuk, and V.V.

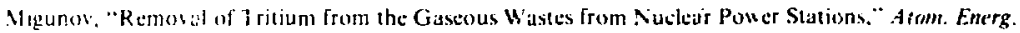
38. $217(1975)$.

37. J. I. Anderson. "Triatuin Containneent and Cleanup Technology in the Tritium Systems Test

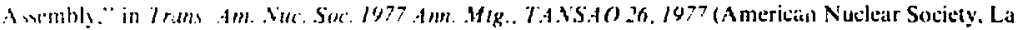
(jrange Park, 1!!. 1477); also L.os Alamos Scientific Laborators, Los Al:tmos, New Mexico, LA-UR 77. $13911977)$.

2x. T $R$ Gillowas. "Tritium Handling in a Mirror-Fusion Central Poutr Station." in Proc. Ind Topical

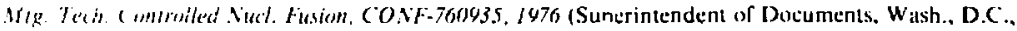
14761.

29. R (i. Aunc. H. P. Cantelow, and R. L. Boltin. "Ptactical Control of Tritit!ded W atter Vapor by Silica Giel and of Tritium (jas by lise of a Purging Device." Tritium. A. A. Moghissi and M. W. Carter, Eds. (Mesenger (iraphics. Phosnix, Aris., 1971).

30. P. D. Cildea. H. (;. Burnbaum, and W. R. Wal. Wodfication and Tessing of the Sandia Lahoratories fivermure Irtium liecomamination Sysems, Sandia Laboratories, Livermore, Calif., SAND78-8647 (197k).

31. A. 1. Sherwesd. 1.an rence Livermore Laboratory. Livermore, Calil., privale communication (April 19781.

32. P. 1). (iildeal. "Contarinment and Decontamination Syslems Planned for the Tritium Research I.aboratory Building at Sandia Lahoratories, Livermore," in Proci Im. Comf. Radiation Effects and Tritim Tech. CONF 751949. 1976 (National Technical Information Service, Springfield, Virginia, 1976).

33. C. I . Jalkers and M. 1:. Singleton. "Collectson of Deuterium on a Uranium Getter During Dynamic Flow Conditions," in Proc. Int. Comf. Radiation Effects and Tritium Tech., CONF. 750989.1976 (Narional Techricia! InTormation Service, Springfield, Virginia, 1976).

34. M. F. Singleton. C. L. Folkers, and C. M. Griffith, "Assessment of Uranium and Cerium as Hydriding Materials for Hydrogen Isotopes in Flowing Argon," in Trans. Am. Nucl. Soc. 1977 Am. Mtg. TANSAO 26. 1977 (American Nuclear Society, La Grange Park, Ill., 1977).

35. J. L. Maitnschein, "Ftasibility of Chemical Getter Beds in Scavenging Tritium from Inert Gases," Nuc. rech. 38, 387 (1978).

36. R. L. Courtncy, Certification Study on the DPPE-590 Pd-CaCO, Hydrogen Getser Sistem: A Progress Report. Sandia Laboratorics, Albuquerque. New Mexico. SAND-74-0249 (1974).

37. A. R. Kasanjian, Radiation Stabitit! ef a Hydrogen Getter Material (DPPE), Atomics Internutional, Golden, Colo., RF P-2456 (1976).

38. T. H. Batzer, R. C. Burleigh, G. A. Carlson, W, L. Dexter, G. W. Hamilton, A. R. Harvey, R. G. Hickman, M. A. Holiman, E. B. Hooper, R. W. Moir, R. L. Nelson, L. C. Pittenger, W. J. Silver, B. H. Smith, C. E. Tiylor, R. W. Werner, and T. P. Wilcox. Conceptual Design of a Mirrur Reactor for a Fusion Engineering Research Facility (FERF), Lawrence Li\%ermore Laboratory, Livermore, Calif, UCRL51617 (1974).

39. A. B. Johnson, Jr., and T. J. Kabele, "Tritium Containment in Fusion Reactors," in Proc. 2nd Topical Mig Tech. C'murollet! Nucl. Fusion, CONF-760935, 1976 (Superintendent of Documents, Wash., D.C., 1976).

40. H. J. Garber, "TFTR Tritium Handling Concepts," in Proc. Int. Conf. Radiation Effects and Tritium Tech. CONF 750989. 1976 (National Technical Information Service, Springfield, Virginia, 1976). 


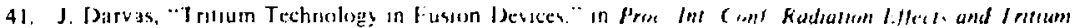

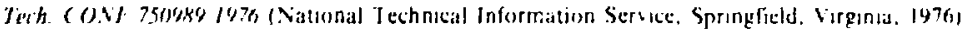

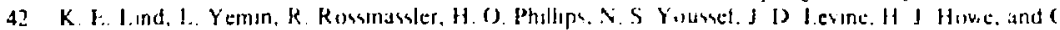

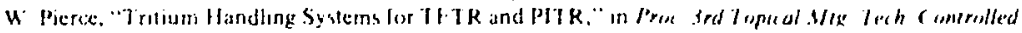

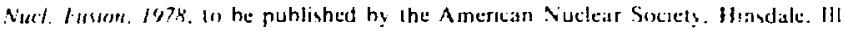

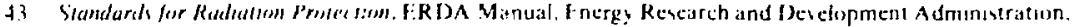
Wash., f)r. ( hanter 0524 11975 ,

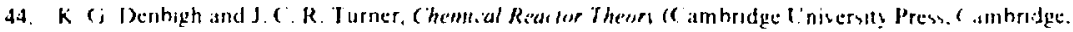

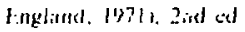

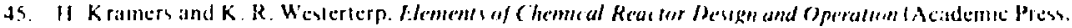
Vicu York (ity, 196,3).

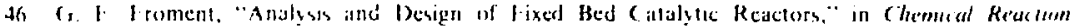
Enginering. 1de (hem Serim lis (Amer. ( hem. Soc. Wash. D.C. 1972).

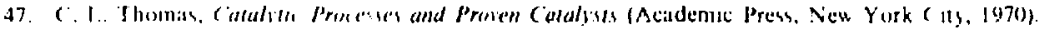

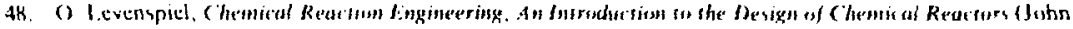
Wiley and Sons, Nen Yurk (ily, 1962).

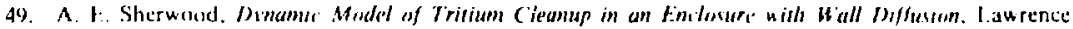

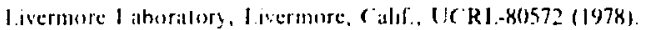

